\title{
A BRÜSSZEL IIA RENDELET SZÜLŐI FELELŐSSÉGET ÉS A JOGELLENES GYERMEKELVITELT ÉRINTŐ FELÜLVIZSGÁLATA
}

\author{
Tóth Barbara \\ egyetemi tanársegéd, Miskolci Egyetem, Európai és Nemzetközi Jogi Intézet \\ 3515 Miskolc, Miskolc-Egyetemváros, e-mail: jogtothb@uni-miskolc.hu
}

\begin{abstract}
Absztrakt
Az Európai Unió müködéséröl szóló szerződés 81. cikke értelmében az Európai Unió a határokon átnyúló vonatkozású polgári ügyek tekintetében igazságügyi együttmüködést alakit ki, és ennek keretében intézkedéseket fogad el. A családok felbomlása esetében ez az együttmüködés különösen fontos ahhoz, hogy biztonságos jogi környezet jöjjön létre, hiszen az egyre fokozódó mobilitása következtében egyre több a nemzetközi vonatkozással bíró család. A tanulmány célja, hogy röviden bemutassa az EU családjogi szabályozásának fejlödését, különös tekintettel a már elfogadott, de még hatályba nem lépett Brüsszel IIb. rendeletre, és annak szülöi felelösséggel és jogellenes gyermekelvitellel kapcsolatos szabályainak megújult szabályaira.
\end{abstract}

Kulcsszavak: joghatóság, Brüsszel IIa. rendelet, Brüsszel IIb rendelet, szülöi felelösség, jogellenes gyermekelvitel

\begin{abstract}
According to Article 81 of the Treaty on the Functioning of the European Union, the Union adopts measures in the field of judicial cooperation in civil matters having cross-border implications. Where families break up, such cooperation is particularly necessary to give a secure legal environment since the growing mobility of citizens within the Union has led to an increasing number of families with an international dimension. This Article aims to briefly introduce the development of EU family legislatyion, in particular, Brussels IIb Regulation, which has already been adopted but has not yet entered into force. and it's renewed rules on parental responsibility and international child abduction.
\end{abstract}

Keywords:jurisdiction, Brussels IIa Regulation, Brussels IIb Regulation, parental responsibility, international child abduction

\section{Bevezetés}

A családjogi ügyekben folytatott igazságügyi együttműködés területén az első elfogadott uniós jogi eszköz az 1347/2000/EK rendelet ${ }^{1}$ volt, amely a házasság felbontásával, a különválással és a házasság érvénytelenítésével, továbbá a házastársaknak a közös gyermekekkel kapcsolatos szülői felelősségére vonatkozó eljárásokban a joghatóságra, valamint a határozatok elismerésére és végrehajtására vonatkozó szabályokat határozta meg. Ezt a rendeletet a Brüsszel IIa. rendelet néven ismert 2201/2003/EK

\footnotetext{
${ }^{1}$ A Tanács 1347/2000/EK rendelete (2000. május 29.) a házassági ügyekben és a házastársaknak a közös gyermekekkel kapcsolatos szülői felelősségre vonatkozó eljárásokban a joghatóságról, valamint a határozatok elismeréséről és végrehajtásáról, HL L 160., 2000.6.30., 19-36.
} 
rendelet $^{2}$ (a továbbiakban rendelet) helyezte hatályon kívül. A rendelet a házassági ügyekben és a szülői felelősséggel összefüggő ügyekben folytatott uniós igazságügyi együttmüködés alapköve. A rendelet egységes szabályokat fogalmaz meg a tagállamok közötti joghatósági összeütközések rendezésére vonatkozóan, továbbá a határozatoknak, közokiratoknak és megállapodásoknak egy másik tagállamban való elismerésére és végrehajtására vonatkozó rendelkezések előírásával megkönnyíti ezen iratoknak az Európai Unióban történő szabad mozgását. A Rendelet 65. cikk úgy rendelkezik, hogy a Bizottság a tagállamok által átadott információk alapján legkésőbb 2012. január 1-jéig jelentést készít az Európai Parlament, a Tanács és az Európai Gazdasági és Szociális Bizottság részére e rendelet alkalmazásáról.

\section{A Brüsszel IIa Rendelet felülvizsgálata}

Ám az előbb említett jelentés ${ }^{3}$ csak 2014 áprilisában készült el. A jelentés a rendelet eddigi alkalmazására vonatkozó első értékelés, és a teljesség igénye nélkül készült. Az Európai Igazságügyi Hálózat (a továbbiakban: EIH) tagjai által a polgári és kereskedelmi ügyekben szolgáltatott adatokon, továbbá a rendelkezésre álló tanulmányokon, a házasság felbontásával kapcsolatos ügyekben alkalmazandó jogról és joghatóságról szóló bizottsági zöld könyvön ${ }^{4}$, a rendelet módosítására irányuló 2006 . évi bizottsági javaslaton, ${ }^{5}$ valamint az 1980. és 1996. évi hágai egyezmények nyomán a Hágai Nemzetközi Magánjogi Konferencia keretében végzett munkán alapul. A jelentés a polgároknak a rendelettel összefüggő leveleit, panaszait, petícióit, valamint az Európai Unió Bíróságának (a továbbiakban: EUB) a rendelettel kapcsolatos ítélkezési gyakorlatát is figyelembe veszi. ${ }^{6}$

A jelentés arra a megállapításra jutott, hogy a rendelet jól müködő eszköz, amely fontos előnyöket biztosított a polgároknak. A joghatósági szabályok átfogó rendszerével, a tagállami központi hatóságok közötti hatékony együttmüködéssel, a párhuzamos eljárások megelőzésével és a határozatok, a közokiratok és az egyezségek szabad áramlásával megkönnyítette a házassági ügyekben és a szülöi felelősségre vonatkozó eljárásokban növekedést mutató, határon átnyúló perek rendezését. Különösen hasznosnak tekinthetők az 1980. évi hágai egyezményt kiegészítő, a gyermek visszavitelére vonatkozó rendelkezések, amelyek célja a gyermek szülő általi jogellenes külföldre vitelétől való visszatartás. A rendeletjavaslathoz kapcsolódó hatásvizsgálat Bizottság által elkészített szolgálati munkadokumentuma $^{7}$ kiemeli, hogy az érdekelt felek - ideértve a tagállamokat is - egyértelmúen szükségesnek tartják a jelenleg hatályban lévő rendelet körültekintő, célzott reformját. Emellett a Juncker-Bizottság politi-

${ }^{2}$ A Tanács 2201/2003/EK rendelete (2003. november 27.) a házassági ügyekben és a szülői felelősségre vonatkozó eljárásokban a joghatóságról, valamint a határozatok elismeréséről és végrehajtásáról, illetve az 1347/2000/EK rendelet hatályon kívül helyezéséröl, HL L 338., 2003.12.23., 1-29.

${ }^{3}$ A Bizottság jelentése a Tanácsnak, az Európai Parlamentnek és az Európai Gazdasági és Szociális Bizottságnak a házassági ügyekben és a szülői felelősségre vonatkozó eljárásokban a joghatóságról, valamint a határozatok elismeréséről és végrehajtásáról, illetve az 1347/2000/EK rendelet hatályon kívül helyezéséröl szóló, 2003. november 27-i 2201/2003/EK tanácsi rendelet alkalmazásáról COM/2014/0225 final

${ }^{4}$ Európai Gazdasági és Szociális Bizottság vélemény Tárgy: „Zöld könyv a házasság felbontására vonatkozó ügyekben alkalmazandó jogról és joghatóságról” $\operatorname{COM}(2005) \quad 82$ final, https://eurlex.europa.eu/legalcontent/HU/TXT/PDF/?uri=CELEX:52005AE1064\&from=SV

${ }^{5}$ Javaslat a Tanács rendelete a 2201/2003/EK rendeletnek a joghatóság tekintetében történő módosításáról és a házassági ügyekben alkalmazandó jogra vonatkozó szabályok bevezetéséről \{SEC(2006) 949$\}$ \{SEC(2006) 950\} /* COM/2006/0399 végleges - CNS 2006/0135*/

6 Jelentés 4.

${ }^{7}$ A Bizottság 2015 májusában tette közzé az Európai Bizottság a „Tanulmány a 2201/2003/EK rendelet értékeléséről és módosításának szakpolitikai alternatíváiról, (végleges értékelő jelentés) 2015. május” c. dokumentumot 
kai iránymutatása hangsúlyozza, hogy fokozatosan javítani kell az uniós tagállamok közötti igazságügyi együttmüködést, lépést tartva jelen korunk Unión belül egyre mobilabb házasodó és gyermeket vállaló polgáraival, a különböző igazságügyi rendszerek áthidalásával és az ítéletek kölcsönös elismerésével, hogy a polgárok Unió-szerte könnyebben gyakorolhassák jogaikat.

Ennek a folyamatnak az eredményeként született meg a házassági ügyekben és a szülői felelősségre vonatkozó eljárásokban a joghatóságról, a határozatok elismeréséről és végrehajtásáról, valamint a gyermekek jogellenes külföldre viteléröl ${ }^{8}$ szóló javaslat, mely 2019 nyarán elfogadásra került. ${ }^{9}$

A tanulmányban igyekeztem jelentés azon pontjait kiemelni, melyek ez európai jogalkotást a rendelet felülvizsgálatára indították. Mivel a felvetett problémák ellenére a megújított rendelet érdemben csak a szülői felelősségre vonatkozó egyes kérdéseken változtat, házassági ügyekben pedig fenntartja a jelenleg is hatályos szabályokat, ezért a tanulmány csak a szülői felelősséget érintő problémákat érinettem.

\section{A javaslat által feltárt problémák}

A rendelet a gyermekek egyenlőségének biztosítása érdekében a házassági eljárásokkal való bármely összefüggéstől függetlenül a szülői felelősséggel kapcsolatos minden döntést lefed. A szülői felelősséggel kapcsolatos ügyekhez tartoznak a gyermek felügyeletével és a gyermek láthatási jogával összefüggő ügyek. Alapvetően hat fö hiányosságot azonosíthatunk a szülői felelősséggel kapcsolatos kérdéseket illetően.

\subsection{A gyermek visszavitelére vonatkozó eljárás}

A visszaviteli eljárás eredménytelensége számos szempontnak tulajdonítható. A gyakorlatban nem bizonyult megfelelőnek a visszaviteli végzés kiadására megadott hathetes határidő, mivel a bírák és joggyakorlók számára nem egyértelmü, hogy a hat hét bírósági szintenként értendő, vagy magában foglalja a jogorvoslatokat vagy akár a visszaviteli határozat végrehajtását is. Nincs arra vonatkozó határidő, hogy a Központi Hatóságnak a beérkező kérelmet mennyi időn belül kell elintéznie. Valamint a nemzeti jogokban nem egységes a visszavitel elrendelése ellen előterjeszthető jogorvoslatok száma. ${ }^{10}$ A másik probléma, a kifejezetten a gyermek visszavitelével foglalkozó szakbíróságok hiánya. Végül a „felülbírálati mechanizmus” gyakorlati alkalmazása is gyakran ütközik nehézségekbe, mivel a felügyeleti jogra vonatkozó eljárásokra nem abban a tagállamban kerül sor, ahol a gyermek tartózkodik, és mivel a gyermeket jogellenesen elvivő szülő gyakran nem hajlandó az együttmüködésre, gyakran nehéz meghallgatni a gyermeket.

A Brüsszel IIb rendelet - az 1980. évi Hágai Egyezmény alapján a visszaviteli ügyeket leggyorsabban kezelő tagállamok között uralkodó nézettel összhangban - egyértelmüvé teszik a végrehajtható visszaviteli végzés kibocsátására rendelkezésre álló határidőt. Egy $6+6+6$ hetes rendszert vezet be (Központi hatóságok, elsőfokú bíróság, másodfokú bíróság). Amennyiben a végrehajtásra a végrehajtási eljárások megkezdésétől számított hat héten belül nem került sor, a végrehajtás helye szerinti tagállam bírósága erről, valamint az időbeni végrehajtás elmaradásának okairól tájékoztatja az eredeti eljárás helye szerinti tagállam megkereső központi hatóságát (vagy amennyiben az eljárásokat a köz-

\footnotetext{
${ }^{8}$ COM/2016/0411 final - 2016/0190 (CNS)

${ }^{9}$ A Tanács (EU) 2019/1111 rendelete (2019. június 25.) a házassági és szülői felelősségi ügyekben a joghatóságról, a határozatok elismeréséröl és végrehajtásáról, valamint a gyermekek jogellenes külföldre viteléről (a továbbiakban Brüsszel IIb rendelet)
}

${ }^{10} \operatorname{COM}(2016) 411$ final, 3. 
ponti hatóság közbenjárása nélkül végezték, a kérelmezőt). A rendelet egyre korlátozza a visszaviteli határozattal szembeni lehetséges jogorvoslatok számát, és kifejezetten felkéri a bíróságot annak mérlegelésére, hogy a visszavitelt elrendelő határozat ideiglenesen végrehajtható legyen-e.

\subsection{A gyermek elhelyezése másik tagállamban}

A Brüsszel IIb rendelet újítása, hogy az elhelyezésről szóló határozatokat illetően önálló hozzájárulási eljárást kell létrehozni, amelyet minden határon átnyúló elhelyezésre alkalmazni kell, és amelyet ki kell egészíteni a megkeresett tagállamra vonatkozó válaszadási határidővel.

\subsection{Az exequatur eljárás követelménye}

A rendelet volt az első uniós eszköz, amely eltörölte az exequatur-t a polgári ügyekben hozott bizonyos ítéletek tekintetében, de csak a láthatási jogokról szóló igazolt határozatok és a gyermek jogellenes elvitele esetén hozott igazolt, visszavitelt elrendelő határozatok esetében. A Brüsszel IIb rendelet kiterjesztette a határozatok kölcsönös elismerésének elvét a szülöi felelösséggel kapcsolatos valamennyi határozat tekintetében, teljesítve ezáltal a Stockholmi Programmal összhangban a kölcsönös elismerési program első szakaszát.

\subsection{A gyermek meghallgatása}

A felülvizsgált rendelet a határozatok elismerésének megtagadási okai között nevesíti a gyermek meghallgatását. ${ }^{11}$ A bírói gyakorlatból látható, hogy a szülői felelősségre vonatkozó eljárásokban az elismerés megtagadásának gyakran használt jogalapja volt az, hogy a határozatot a gyermek meghallgatása nélkül hozták. A rendelet azon az elven alapul, hogy a gyermek véleményét figyelembe kell venni az öket érintő esetekben, amennyiben ez életkoruk és érettségi fokuk tekintetében megfelelö, és összhangban van mindenekfelett álló érdekeikkel. Nehézségek mutatkoznak amiatt, hogy a tagállamok eltérő szabályokkal rendelkeznek a gyermek meghallgatására vonatkozóan. A gyermek meghallgatását illetően a határozat eredeti eljárásának helye szerinti tagállamnál szigorúbb előírásokat alkalmazó tagállamokat a jelenlegi szabályok arra ösztönzik, hogy utasítsák el az elismerést és a végrehajthatóvá nyilvánítást, amennyiben a gyermek meghallgatása nem felel meg saját eljárásaiknak. Emellett a Brüsszel IIa rendelet a szülői felelősségre vonatkozó összes ügyben általánosságban nem, csupán a visszavitellel kapcsolatos eljárásokban hangsúlyozza a gyermek meghallgatásának fontosságát. ${ }^{12}$

A Brüsszel IIb rendelet érintetlenül hagyja a gyermek meghallgatására vonatkozó tagállami szabályokat és gyakorlatokat, de előírja a jogrendszerek kölcsönös elismerését. Ez azt jelenti, hogy a rendelet kifejezetté tenné azt a kötelezettséget, hogy a véleményalkotásra képes gyermek számára kötelező lehetőséget biztosítani e vélemények kifejezésére, szem előtt tartva azt, hogy minden tagállam megerősítette az ENSZ gyermekjogi egyezményét, amely már kötelezi őket a fenti feltételnek megfelelő gyermekek meghallgatására az öket érintő összes hazai és határon átnyúló eljárásban. Egy, a másik tagállamban hozott határozatot elismertetni kívánó szülő számára ez azt jelenti, hogy az adott országban múködő bíróság nem tagadja meg a határozat elismerését pusztán amiatt, hogy az említett bíróság által alkalmazott előírásokkal összevetve a gyermeket a másik országban másként hallgatták meg.

\footnotetext{
11 23. cikk: A szülői felelősségére vonatkozó határozat nem ismerhető el, amennyiben: [...]

b) ha - a sürgős eseteket kivéve - a határozatot úgy hozták meg, hogy nem adtak lehetőséget a gyermek meghallgatására, megsértve ezzel annak a tagállamnak az eljárási alapelveit, ahol az elismerést kérik;

${ }^{12} \operatorname{COM}(2016) 411$ final, 4-5.
} 


\subsection{A határozatok végrehajtása}

A szülői felelősségre vonatkozó határozatokat gyakran későn, vagy egyáltalán nem hajtják végre. A családdal kapcsolatos határozatok végrehajtására alkalmazott jogi és gyakorlati megközelítés tagállamonként változó. ${ }^{13}$ Mivel a végrehajtási eljárást a végrehajtás helye szerinti tagállam joga szabályozza, és különbségek vannak a különbözö nemzeti jogszabályok között, nehézségek merülnek fel a szülöi felelősséggel kapcsolatos döntések végrehajtása során. Néhány nemzeti rendszerben nincsenek külön szabályok a családjogi döntések végrehajtására, és a feleknek a rendes polgári vagy kereskedelmi jogi döntések végrehajtására rendelkezésre álló olyan mechanizmusokat kell igénybe venniük, amelyek nem veszik figyelembe azt, hogy a szülői felelősség területén az idő múlásával visszafordíthatatlan következményekhez vezet.

A Brüsszel IIb rendelet garantálja, hogy a végrehajtást csak egységes és korlátozott megtagadási indokok alapján tagadhassák meg. A végrehajtásra vonatkozóan is határidőt szab, és annak túllépése esetén jelentéstételi kötelezettséget ír elö, valamint biztosítja annak lehetőségét, hogy az eredeti eljárás helye szerinti tagállam egy határozatot - az azzal szembeni fellebbezések ellenére - ideiglenesen végrehajthatóvá nyilvánítson, ezzel egyidejűleg lehetőséget hagyva arra, hogy a gyermek mindenek felett álló érdekét fenyegető sürgős veszélyekkel a végrehajtási szakaszban foglalkozzanak, ami viszont egyértelmüen megerősíti az eljárások hatékonyságát, valamint a gyermek mindenek felett álló érdekének védelmét. Ennek eredményeként egy szülő az ideiglenesen végrehajthatóvá nyilvánított határozat alapján megkapná a gyermek láthatásának jogát, miközben az említett határozattal szemben a másik szülő kérésére fellebbviteli eljárás van folyamatban.

\subsection{A központi hatóságok közötti együttműködés}

A Központi Hatóságok létrehozásának célja, hogy az a szülő, akitől a gyermeket jogellenesen elvitték, a lehető legegyszerübb módon, a saját államában tudja kérelmét előterjeszteni, és ezt követően a két érintett tagállam Központi Hatóságai közvetlenül tartják a kapcsolatot egymással az ügy megoldása érdekében. Az összes érdekelt fél - ideértve a tagállamokat is - problémát észlelt azzal kapcsolatban, hogy a központi hatóságok által a szülői felelősségre vonatkozó konkrét esetekben nyújtandó támogatást elöíró cikk megfogalmazása nem egyértelmü. Ez késedelmeket okozott, ami árt a gyermekek mindenek felett álló érdekének. ${ }^{14}$

A Brüsszel IIb. rendelet egyértelmüvé teszi az alábbi vonatkozásokat: ki kérhet; milyen segítséget vagy információt; kitől és milyen körülmények között. Azt is egyértelművé teszi, hogy a bíróságok és gyermekjóléti hatóságok is kérhetnek segítséget a központi hatóságoktól. Továbbá kimondja, hogy a tagállamok biztosítják, hogy a központi hatóságok megfelelő pénzügyi és emberi erőforrással rendelkezzenek ahhoz, hogy elláthassák az e rendelet alapján rájuk ruházott kötelezettségeket.

\section{4. Összefoglalás}

Összességében elmondható, hogy az új Brüsszel II. rendelet alapvetően jól funkcionál, és alapvető értéket képvisel a családjogi ügyekben folytatott igazságügyi együttmüködés területén, azonban az értékelő jelentésből láthatjuk, hogy vannak olyan területek, ahol a tagállamok közötti együttmüködés, és ezáltal az uniós polgárok igényérvényesítése még hatékonyabbá tehető. A Brüsszel IIb rendelet az értékelő jelentésben tett megállapításokra figyelemmel megpróbálja orvosolni a rendelet gyakorlati

\footnotetext{
${ }^{13} \operatorname{COM}(2016) 411$ final, 5.

${ }^{14}$ COM(2016) 411 final, 5.
} 
alkalmazásában megmutatkozó hibákat, hiányosságokat, megújítva ezzel a tagállamok közti igazságügyi együttmüködés családjogi területét. Véleményem szerint a pontosítások hozzájárulnak a jogalkalmazás egyszerüsítéséhez, növelik a jogbiztonságot és a kiszámíthatóságot, jelentősen megkönnyítve ezzel a nemzetközi családok helyzetét. Azonban hozzá kell tennünk, hogy a családjogi ügyekben továbbra is elvárt egyhangúság miatt a javaslat továbbra sem rendez olyan kényes kérdéseket, amelyek bizonytalansághoz vezetnek a rendelet értelmezésével kapcsolatban. De reméljük, hogy az új rendelet hatályba lépését követően beváltja a hozzá füzött reményeket. Azonban meg kell várnunk 2022. augusztus 1-jét, amikortól a rendelet szabályait alkalmaznunk kell a hatálya alá tartozó ügyekben.

\section{Köszönetnyilvánítás}

A cikkben ismertetett kutató munka az EFOP-3.6.1-16-2016-00011 jelü „Fiatalodó és Megújuló Egyetem - Innovatív Tudásváros - a Miskolci Egyetem intelligens szakosodást szolgáló intézményi fejlesztése" projekt részeként - a Széchenyi 2020 keretében - az Európai Unió támogatásával, az Európai Szociális Alap társfinanszírozásával valósul meg.

\section{Felhasznált jogforrások és egyéb előkészítő anyagok}

[1] A Tanács 1347/2000/EK rendelete (2000. május 29.) a házassági ügyekben és a házastársaknak a közös gyermekekkel kapcsolatos szülői felelősségre vonatkozó eljárásokban a joghatóságról, valamint a határozatok elismeréséröl és végrehajtásáról, HL L 160., 2000.6.30., 19-36.

[2] A Tanács 2201/2003/EK rendelete (2003. november 27.) a házassági ügyekben és a szülöi felelősségre vonatkozó eljárásokban a joghatóságról, valamint a határozatok elismeréséről és végrehajtásáról, illetve az 1347/2000/EK rendelet hatályon kívül helyezéséröl, HL L 338., 2003.12.23., 1-29.

[3] A Bizottság jelentése a Tanácsnak, az Európai Parlamentnek és az Európai Gazdasági és Szociális Bizottságnak a házassági ügyekben és a szülői felelősségre vonatkozó eljárásokban a joghatóságról, valamint a határozatok elismeréséről és végrehajtásáról, illetve az 1347/2000/EK rendelet hatályon kívül helyezéséröl szóló, 2003. november 27-i 2201/2003/EK tanácsi rendelet alkalmazásáról COM/2014/0225 final

[4] Európai Gazdasági és Szociális Bizottság vélemény Tárgy: „Zöld könyv a házasság felbontására vonatkozó ügyekben alkalmazandó jogról és joghatóságról” $\operatorname{COM}(2005) 82$ final, https://eur-lex.europa.eu/legalcontent/HU/TXT/PDF/?uri=CELEX:52005AE1064\&from=SV

[5] Javaslat a Tanács rendelete a 2201/2003/EK rendeletnek a joghatóság tekintetében történő módosításáról és a házassági ügyekben alkalmazandó jogra vonatkozó szabályok bevezetéséről $\{\operatorname{SEC}(2006) 949\}\{$ SEC(2006) 950\}/* COM/2006/0399 végleges - CNS 2006/0135*/

[6] Európai Bizottság „Tanulmány a 2201/2003/EK rendelet értékeléséről és módosításának szakpolitikai alternatíváiról, (végleges értékelő jelentés) 2015. május" COM/2016/0411 final 2016/0190 (CNS)

[7] A Tanács (EU) 2019/1111 rendelete (2019. június 25.) a házassági és szülöi felelősségi ügyekben a joghatóságról, a határozatok elismeréséről és végrehajtásáról, valamint a gyermekek jogellenes külföldre viteléről HL L 178., 2019.7.2., 1-115. o. (Brüsszel IIb rendelet) 